\title{
The Composition and Structure of Reef Community at Tho Chu Island (South China Sea) after Ketsana Typhoon
}

\author{
Yuri Ya. Latypov \\ A.V. Zhirmunsky Institute of Marine Biology, Far East Branch of Russian Academy of Sciences (FEB RAS), Vladivostok, Russia \\ Email: 1tpv@mail.ru
}

Received August 5, 2013; revised September 7, 2013; accepted October 5, 2013

Copyright (C) 2013 Yuri Ya. Latypov. This is an open access article distributed under the Creative Commons Attribution License, which permits unrestricted use, distribution, and reproduction in any medium, provided the original work is properly cited.

\begin{abstract}
Fringing the reefs of the island Tho Chu explored a quarter century later now reexamined in the Gulf of Thailand of the South China Sea. It was found that most of the reefs of the island were lost after the passage of typhoon "Ketsana" accompanied by heavy rains and strong sea waves higher than 2 meters in October 2009. Because of these natural phenomena, physical destruction of many of the coral communities occurred. Removal of terrigenous sediments from the islands in the water has led to increased sedimentation and loss of almost all the scleractinian family Acroporidae, the main building corals on the reefs of the Indo-Pacific, at present, in places where once there was full-reef community succession restoring the reef due to the survivors of the typhoon colonies of coral genera Pocillopora and Acropora.
\end{abstract}

Keywords: Typhoon Ketsana; Destruction; Reef Community; Change; Succession; Vietnam

\section{Introduction}

Coral reefs are under threat worldwide. An estimated $58 \%$ of reefs are classified as threatened [1], and $11 \%$ of the original extent of coral reefs have already been lost [2]. The composition of remaining coral reefs is also changing rapidly. For example, coral cover on reefs across the Caribbean has decreased by $80 \%$ in the past three decades [3], and some formerly abundant coral species have almost disappeared from the region [4]. The causes of coral decline are thought to include a combination of direct anthropogenic factors, such as overfishing, pollution, and sedimentation [5]. Hurricanes and tropical storms are perhaps the most obvious and frequent natural disturbances affecting reef communities. They have long been recognized as being important determinants of both the structure and function [6-8] of reef ecosystems. A number of studies have documented the severe immediate consequences of hurricane impacts at single sites in terms of reduced coral cover $[9,10]$, highlighting the effects as being impressive in magnitude, speed, and patchiness.

Vietnamese island of the Gulf of Thailand for the most part is open all year co wind waves in all directions. Their slopes are formed by underwater boulders and boulder heaps of moving from deep stony deposits, and on to the platform of sand and silt. Openness and vulnerability of islands, shallow water of the coastal zone make them prone to intense excitement even during strong winds. In times of typhoons, such excitement leads to severe physical damage and destroying fragile coral colonies falling asleep and their bottom sediments. This peculiarity of the coastal geomorphology and hydrology of the region affects the formation of his few reefs, which are also often subject to strong typhoons. So in October 2009, the Vietnam landfall of typhoon "Ketsana", which reached gusts of wind up to $165 \mathrm{~km} / \mathrm{h}$ corresponded to category 2 on a scale Saffir-Simpson Hurricane. Typhoon was accompanied by heavy rainfall (about $200 \mathrm{~mm}$ of rain), and the excitement of the sea more than two meters tall. After comparable in strength typhoon corals are destroyed at depths greater than $12 \mathrm{~m}-60 \%$ to $80 \%$-between $12 \mathrm{~m}$ and $30 \mathrm{~m}$ and $100 \%$ - beyond $35 \mathrm{~m}$, where as earlier living coral cover age ranged from 60 to $75 \%$ in these zones [11]. As is well known, flows of storm (flash flood) of wastewater and desalination are characterized by strong turbidity due to the large number of different particulate matter, which have a detrimental effect on the existence of coral communities, leading to their partial and sometimes total loss $[12,13]$. Most of the reefs of the island Tho Chu were virtually destroyed. When the coastal zone at depth of $5.3 \mathrm{~m}, 40 \%$ of its corals were destroyed; at depth of $5-8 \mathrm{~m}$ in the settlement of Acropora- $100 \%$; at depth of $8-12 \mathrm{~m}$ $-60 \% ; 5.3 \mathrm{~m}, 40 \%$ of its corals were destroyed; at depth of 
$5-8 \mathrm{~m}$ in the settlement of Acropora- $100 \%$; at depth of 8 $12 \mathrm{~m}-60 \%$; at depth of $12 \mathrm{~m}-10 \%$. In this regard, it is appropriate to go back briefly to the information about the state of these reefs of quarter century ago.

First reefs in this region have been studied in detail in the joint Soviet-Vietnamese expeditions in 1986 and 2007, and then World Wildlife Fund (WWF) in 19921993 [14-17]. There are clarified species composition, population density of dominant species of macrobenthos and the degree of coverage of the substrate corals and macrophytes. Through identifying these reefs based on the data points of the coral community, it shows that the reefs are quite satisfactory and similar with those of North and South Vietnam and the Indo-Pacific [18-21].

Tho Chu Island $\left(9^{\circ} 18^{\prime} \mathrm{N}, 103^{\circ} 28^{\prime} \mathrm{E}\right)$, together with surrounding rocks and small islets is about $11 \mathrm{~km}$ in diameter (Figure 1). The relief of the island represents a high plateau bordered by steep abrasion denudation slopes. It is a remnant of a large sub platform structure destroyed in the Pleistocene because of a tectonic immersion of the bottom in the Gulf of Siam. The island consists of coarse layered sub horizontal sandstones and conglomerates of coastal-marine genesis, which is evidenced by well-rolled gravels, shoestring distribution of pebbles, and the pattern of rhythmic and textured sediments that is characteristic of coastal shallows. The development of the ruinedrocky submarine relief is, to a significant degree, due to these geomorphologic peculiarities. The submarine slopes represent boulder-block bottoms transforming in deeper depths into stony and gravel deposits, which, in deeper depths, replaced by sandy-corallogenic deposits with great amounts of organic detritus. The northern and northeastern slopes have ratios of $0.05-0.08$ going down to a platform at a depth of $35-40 \mathrm{~m}$. In the south and southeast, the slope ratio is $0.032-0.044$ and the slope transforms into the platform at a depth of $23-25 \mathrm{~m}$. An ingressive sandy bay with a slope ratio of 0.026 and a wide zone of wave accumulation in the innermost part is set into the western coast.

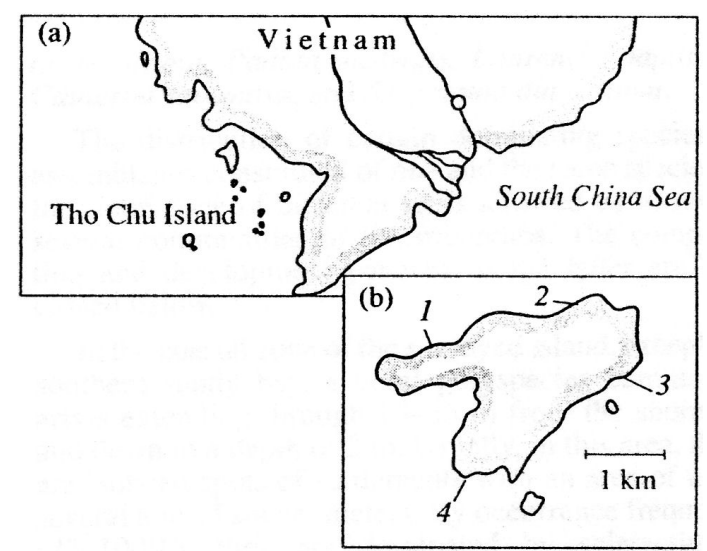

Figure 1. Schematized map showing the location of Tho Chu Island (a) and the position of transects 1-4 (b).
The re-examination reefs in 2010 and 2013 on the same cuts as in the $80 \mathrm{~s}$ of the last century have been found significant changes in the composition and structure of reef communities. Therefore, these results of the studied reefs in the region, in our view, are interesting, and as an independent study, they can also be used as material for comparison with the changes taking place on the reefs not only in the central and southern Vietnam, but also throughout the entire Pacific.

\section{Materials and Methods}

Using SCUBA equipment, we investigated the composition, distribution of scleractinian corals and mass species of macrobenthos, structure of communities in reef zones at four sections in sandy and stony inlets and near rocky coasts (Figure 1). Investigations were carried out in accordance with the standard hydrobiological technique using quadrats and transects $[22,23]$. Abundance of mass species of mollusks and echinoderms, branched, massive, encrusted and funnel-shaped scleractinian colonies, as well as the degree of substrate cover by corals were estimated along a $150 \mathrm{~m}$ transect frame divided into 100 squares with the area of $10 \mathrm{~cm}^{2}$ each. Photographing of reef landscapes, and their flora and fauna was conducted. More than 750 photos by Olympus and Lumix digital cameras were made for later analysis of species composition [24, 25 ] and structure of community of coral reef survey methods [26-28]. Coefficients of species diversity corals were calculated by the formula:

$\boldsymbol{H}=-\sum[(\boldsymbol{n i} / \boldsymbol{N}) \boldsymbol{x}(\operatorname{lnni} / \boldsymbol{N})]$, where $\boldsymbol{H}$-Shannon Diversity Index, $\boldsymbol{n i}$ - number of individuals belonging to $\boldsymbol{i}$ species, $N$-total number of individuals [29].

\section{Results and Discussion}

In 1986 , the diversity of species on different reefs varied from 335 to 387 species, of which 275 species in total were scleractinian. Ubiquitous and often dominated by 37 species: sponge Petrozia testudinaria; corals Sarcophyton trocheliophorum, Sinularia dura, Lobophytum pauciflorum, Junceella fragilis, Seriatopora hystrix, Pocillopora damicornis, Acropora nobilis, A. cytherea, Pavona decussata, Pachyseris rugosa, Diaseris distorta, Polyphyllia talpina, Galaxea fascicularis, Lobophyllia hemprichii, L. hattai, Goniopora stokesi, Platygyr daedalea, Diploastrea helioporau Millepora platyphylla; mollusks Cyprea tigris, Beguina semiorbiculata и Malleus malleus; echinoderms Holothuria atra, H. edulis, Stichopus variegatus, Bohadshia graeffei, Diadema setosum, Echinotrix diadema, Culcita novaeguineaе и Linckia laevigata; polychaetes Spirobranchus giganteus; and algae Turbinaria ornata, Padina australis, Laurencia papilosa, Caulerpa racemosaи Sargassum duplicatum.

Distribution of certain dominant species or groups of 
the same species in different zone of the same reefs revealed several macrobenthos of communities. The composition and characteristics of formation of which are discussed below.

In the coastal zone of the studied island, except the southern sandy bay, a coral formed polyspecific community arises extending through 15 - $35 \mathrm{~m}$ from the shoreline to a depth of $2 \mathrm{~m}$. Usually, in this area, there are separate spots of settlements with an area of up to a few tens of square meters. In terms of frequency of occurrence (75\% - 100\%) predominated scleractinian P. daedalea, $P$. verrucosa, Acropora millepora, A. robusta and hydroid $M$. platyphylla, were also distributed to individual colonies and settlements of soft corals $S$. trocheliophorum (biomass of $3050 \mathrm{~g} / \mathrm{m}^{2}$ ) and L. pauciflorum $\left(2680 \mathrm{~g} / \mathrm{m}^{2}\right.$ ). The largest coral cover substrate does not exceed $40 \%$. Constant components of the coral community were algae $L$. papilosa and $T$. ornata, with a predominance of the first of them (up to $376 \mathrm{spec} . / \mathrm{m}^{2}$ at biomass $3516 \mathrm{~g} / \mathrm{m}^{2}$ ), clam C. arabica, echinoderms D. setosum and N. atra. A polychetes $S$. giganteus (up to $179 \mathrm{spec} . / \mathrm{m}^{2}$ ) is always present in the branches of the colonies hydroid M. platyphylla.

The coastal polyspecific coral-algal community is replaced by a community of Acropora + Diploastrea, which develops in the area from the reef front zone down to the lower part of reef slope, extending for $50-100 \mathrm{~m}$ along the slope, in depths of 2 to $15 \mathrm{~m}$ deep. No absolute domination of any Acropora species is observed there. This community represents extended spots of solid populations, with $100 \%$ substrate coverage by one of the following species: A. nobilis, A. cytherea, A. rnicrophthalma, A. divaricata, or $A$. florida. The subdominants are $D$. heliopora (large massive colonies up to $2-3 \mathrm{~m}$ in diameter) and encrusting-lamellate colonies of Euphyllia orphensis (up to $2 \mathrm{~m}$ in diameter); they encountered in $70 \%-100 \%$ of cases. This community is characterized by rich taxonomic diversity of scleractinian (more than $60 \%$ of the total species diversity). Each of the genera Montipora, Pontes, Fungia, Symphyllia, Favia, Favites, Pavona, Echinophyllia, Montastrea, and Lobophyllia is often represented there by several species. The degree of substrate coverage by corals totals, as a rule, more than $60 \%$ and reaches $100 \%$ in the spots of monosettlements. In the windward reefs of the northern side of the island, in the community of Acropora + Diploastrea, on a submerged terrace, a facies of $A$. nobilis $+A$. microphthalma has developed with almost solid coverage by substrate by the corals of these two species.

A community of Junceella fragilis + Diaseris distorta develops in gravel-sandy bottoms with numerous small coral fragments, at a depth of $15-18 \mathrm{~m}$. The basis of this community is constituted by gorgonian $J$. fragilis and single mushroom-shaped corals $D$. distorta that dominate all other macrobenthos species by population density (18 and $20 \mathrm{spec} . / \mathrm{m}^{2}$ respectively). Besides the dominating species, constant components of this community are other species:corals Verrucella umbraculum, S. dura, Cycloseris costulata, Fungia fungites, and Polyphyllia talpina, sponge $P$. testudinaria, echinoderms $B$. graeffei, $H$. edulis and Toxopneustes pileolus. Among the associated macrobenthos, the corals Turbinaria peltata, S. hystrix, Goniopora stokesi, Leptastrea pruinosa, and Favia speciosa; holothurians $S$. variegates and Halodeima edulis, seastar Culcita novaeguineae and gastropods Cyprea tigris and Cassis cornuta are most often encountered.

A community of the reef slope is characterized by a great degree of substrate coverage $(75 \%-100 \%)$ and the greatest species diversity of macrobenthos (about $70 \%$ of the registered species diversity), which is characteristic of the reef zone in the Indo-Pacific [14,20,30-35]. It is formed in the depth of $3-12 \mathrm{~m}$ and extends for $120-150$ $\mathrm{m}$ along the reef slope. The upper part of the slope, as in the reef flat, is dominated by $A$. cytherea, A. hyacinthus, and $A$. nasuta. Large lamellate colonies (1.2 - $2 \mathrm{~m}$ in diameter) of $M$. aequituberculata and $M$. hispida distributed amongst the colonies of these three species. The area of coverage by monospecific settlements of $P$. rus and large colonies of D. heliopora increases up to $30 \%$ $40 \%$ in the middle part of the reef slope. The diversity of other scleractinian species (faviids, fungiids, and encrusting-lamellate colonies of the genera Euphyllia, Echinipora, Pachyseris, Micedium, and Merulina) increases and reaches 147 species. The dominance of any coral species is not observed in the lower part of the slope. A significant role-played in this part of the reef by funnel form and encrusting species and colonies with rather large corallites is represented by different species of the genera Turbinaria, Pavona, Euphyllia, Physogyra, Galaxea, Lobophyllia, and Symphyllia. The degree of substrate coverage by corals falls down to $20 \%-30 \%$. In the massive colonies of the corals Porites, Platygyra, and Astreopora, there are settlements of mollusks $B$. semiorbiculata, $A$. ventricosa, and $P$. pinguin with the mean density of 2.8 $4.2 \mathrm{spec} . / \mathrm{m}^{2}$ and the domination of $A$. ventricosa (up to $10.9 \mathrm{spec} . / \mathrm{m}^{2}$, with the biomass of $455.6 \mathrm{~g} / \mathrm{m}^{2}$ ). The oyster $L$ cristagalli $\left(0.5 \mathrm{spec} . / \mathrm{m}^{2}\right)$ and the mollusk $T$. squamosa $\left(1.5-2.0\right.$ spec. $\left./ \mathrm{m}^{2}\right)$ are continuously encountered. The sea urchins $D$. setosum and E. diadema and holothurians $S$. variegatus and B. graejfei are common in the community of the reef slope in this part of Tho Chu Island, as well as in the communities described above.

Typhoon caused significant damage of richness scleractinian species declined by almost a third (from 275 to 95 species). There are decreased by 2 - 3 times of substrate coral cover as well as an index of species diversity (Figures 2 and 3). The number of related corallobionts: clams, gastropods, sea cucumbers and sea stars, sea urchins, with the exception of D. setosum, E. 

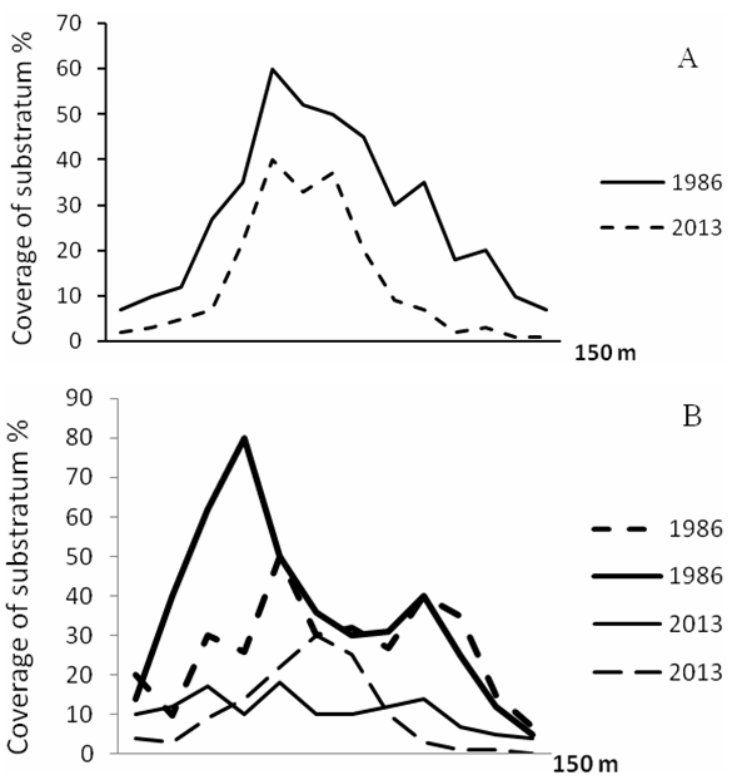

Figure 2. Coverage of the substrate corals: A. Common, B. Branched (solid line) and massive (dashed line) colonies.

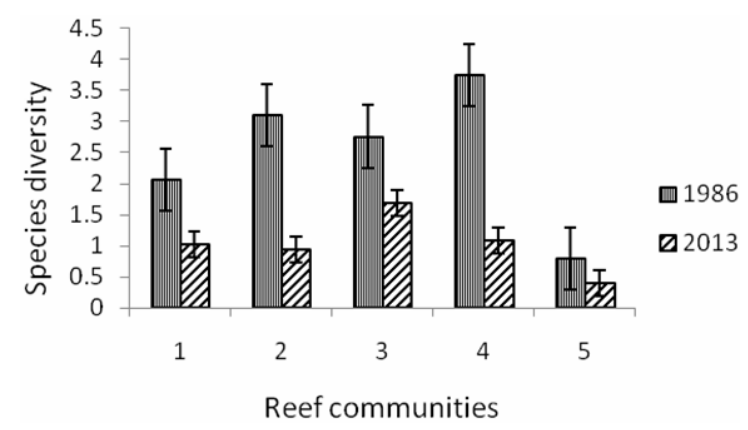

Figure 3. Variations of a specific diversity on the investigated reefs. 1. coastal polyspecific community; 2 . fascia $A$. nobilis + A. microphthalma; 3. community Acropora + Diploastrea; 4 . community of reef slope; 5 . community Junceella fragilis + Diaseris distorta.

diadema and T. pileolus is also reduced. Although this reduction is probably not due to the influence of the typhoon, and the omnipresence of the hose diving equipment, with which listed aquatic actively fished by all Vietnamese reefs. Recovery of structure reefs zone, composition and structure of coral communities occurred mainly in the south-eastern side of the island (transect 3, $9^{\circ} 18^{\prime} \mathrm{N}$., $108^{\circ} 29^{\prime} \mathrm{E}$ ). This typhoon outlives specimen of corals with large corallites: Diploastrea heliopora, Turbinaria peltata, Astreopora microphthalma, up to 2 - 3 species from Euphyllidae (Euphyllia, Plerogyra) and Mussidae (Lobophyllia, Symphyllia), large specimen of Fungia, and large massive colonies of Porites. The abundance of poritids accounted for by their ability to secrete a firm mucous covering and starter production 1 2 months earlier than other coral species. These peculiarities favor their better adaptation to water overheating, and desalination under other stressful conditions of silted shallow water [36-39]. Scleractinian and several species of Pocillopora come off outlive remnant animated due to its farness from shorefront to depth $12-15$ meters. This is known that Pocillopora even damaged 25\% preserve to two thirds of productive capacity and settling [40].

The community Junceella fragilis + Diaseris distorta of for reef platform (depth of $16 \mathrm{~m}, 125 \mathrm{~m}$ from the shoreline) was transformed into settlements that are only one of the gorgonian with a density of 4.5 to 12.0 spec. $/ \mathrm{m}^{2}$ and individual colonies Sinularia, Astreopora, Pocillopora, Porites, Favia, Favites and single young Fungia, still attached to the substrate. Here there are uncommon sponge $P$. testudinaria and sea urchins $E$. diadema and T. pileolus, single starfish $C$. novaeguineae. Dominated in this community fungiids $D$. distorta, as well as the formerly common species of $4-5$ other single mushroom scleractinian corals were not met.

At a depth of $6-8$ meters and a distance of $50-40$ meters from the shoreline spreads the zone of dead Acropora (Figure 4) spreads on the site of pre-existing fasces A. nobilis + A. microphthalma. Currently, there is formed polyspecific settlement of corals survived the typhoon and re-inhabiting species of scleractinian and alcyonarian. The most common here are Faviidae (D. heliopora, Favia - 5 species, Favites -3 species), Poritidae -7 species, Fungiidae - 6 species for 3 species of genus Lobophyllia, Symphyllia and Pavona. The most diverse are coral genus Acropora-12 species, but they met only unitary colonies, with the exception of $A$. cytherea and $A$. gemmifera, 4 and 3 colonies are observed in the meter area transect. Here, there are settlements of soft corals $S$. trocheliophorum, covering the surface of the substrate to a rock 40\% - 70\%. On clearing free of dead Acropora formed settlements of various Fungia (14 - 16 specimen $/ \mathrm{m}^{2}$ and 4 6 species) of different age and size characteristics.

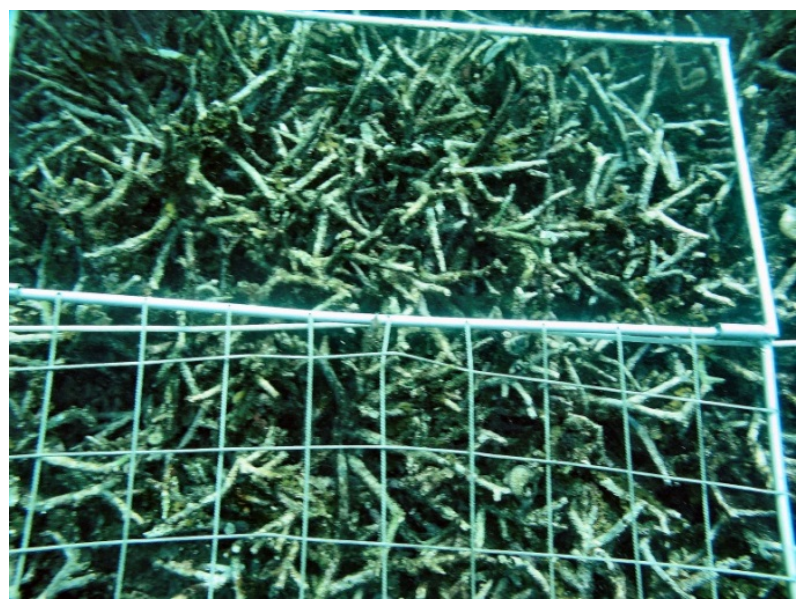

Figure 4. Completely destroyed by the typhoon Acropora from the former fasces $A$. nobilis $+A$. microphthalma, depth $4 \mathrm{~m}$. 
There are also visible remains of the dead fungiids (Figure 5). In general, there is another stage of succession reef community-its rebirth. Ubiquitous young colonies (size 3 - $5 \mathrm{~cm}$ ) Acropora, Favia, Favites, Goniastrea, and Fungia settle on a free dead Acropora substrate. So, newly settled Acropora successfully grow (Figure 6).

With 100 meters of the coast at a depth of 12 meters is now formed community Pocillopora + Junceella, which is based on the survival of the typhoon and re-settling colonies of these cnidarians (Figure 7). This community extends over a distance of $40-60$ meters to a depth of 8 meters with a population density of gorgonians to $25 \mathrm{spec} . / \mathrm{m}^{2}$ and coating the surface of the substrate of Pocillopora to $70 \%$. Besides the three species of Pocillopora (damicornis, meandrina and verrucosa) and large colonies Diploasrea heliopora in this community are common, individual colonies include Porites australiensis, Lobophyllia robusta, L. hemprichii, L. flabelliformis, Galaxea fascicularis, Euphyllia divisa, Fungia fungites, Pavona explanulata and

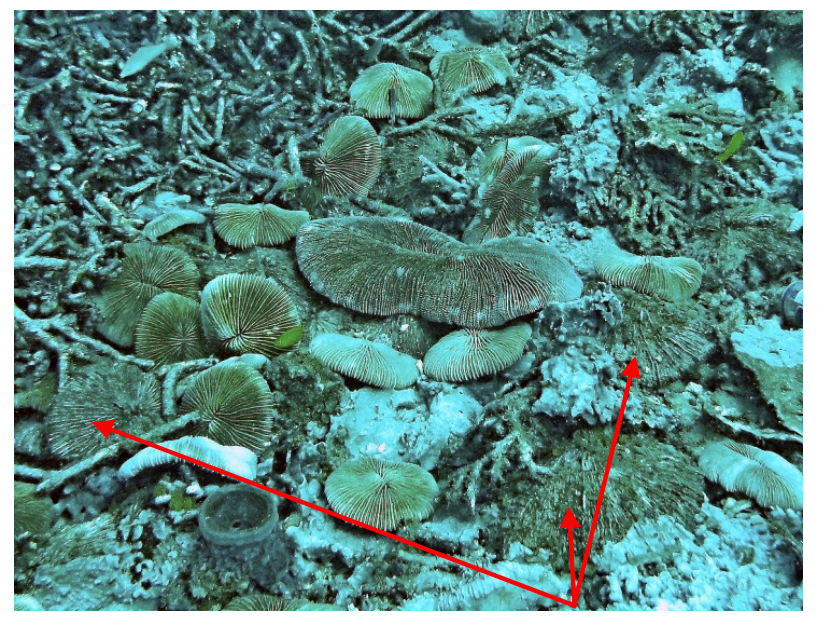

Figure 5. Settlement of Fungia, seen dead corals, depth 5 m.

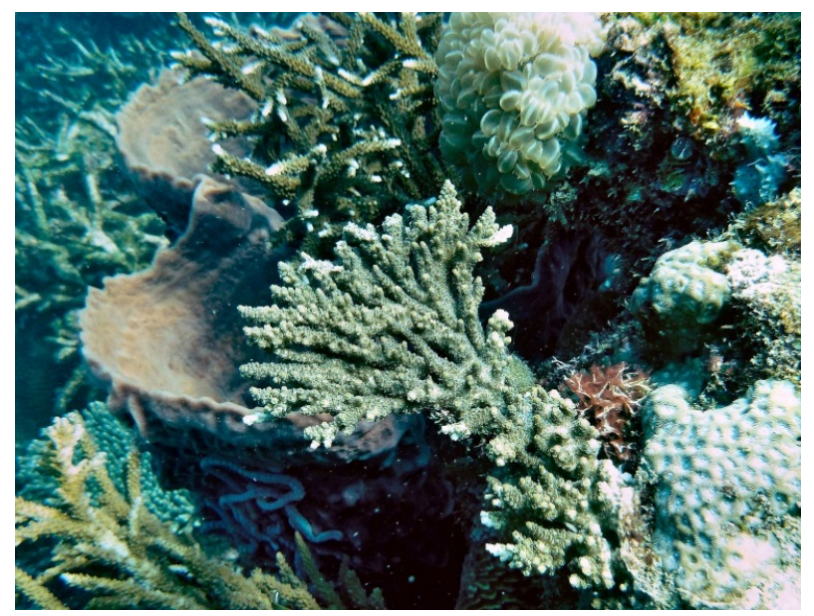

Figure 6. Scleractinian settlement on the free hard substrate in the former zone of Acropora + Diploastrea, depth $\mathbf{3}$ m.

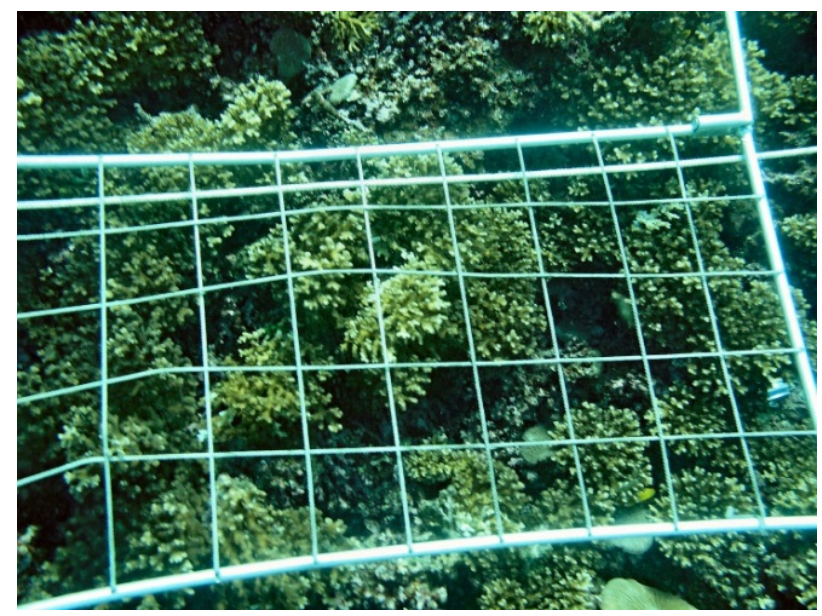

Figure 7. Recovery settlements of Pocillopora (existed in 1986), coated surface of the substrate of Pocillopora to $70 \%$, depth $11.5 \mathrm{~m}$.

single Acropora abrolhosensis, A. gemmifera, and Montipora grisea. Concomitant spread of macrobenthos sponge $P$. testudinaria is up to 1.2 meters high and 0.6 meters in diameter, sea urchins $D$. setosum to $14 \mathrm{spc} . \mathrm{m}^{2}, E$. diadema to $2 \mathrm{spec} . / \mathrm{m}^{2}$, T. pileolus $-0.2 \mathrm{spec} . / \mathrm{m}^{2}$, as well as individual Tridacna crocea, Trochus niloticus, Pteria penguin, Mauritia arabica and Holothuria atra.

Rocky coastal area was the most taxonomically rich. It was most likely to be preserved corals with massive and encrusting forms colonies between large rocky boulders several feet across. This area is still formed polyspecific community scleractinian and alcyonarian consisting of 40 - 50 species, of which the most common are Acropora millepora, Diploastrea heliopora, Goniastrea aspera, Echinopora lammelosa, Euphyllia divisa, Lobophyllia robusta, Montipora grisea, Pavona decussata, Plerogysa sinuosa, Symphyllia recta, and by 2 - 3 species of Favia and Porites. There are also common colony $S$. troheliophorum, Lobophytum pauciflorum and Zoanthus ssp. near the water's edge marked by some bushes macrophytes $T$. ornatum and Laurencia papilosa. In the colonies of Porites constantly meet bivalve's $B$. semiorbiculata (from two to seven individuals per colony) and the polychetes $S$. giganteus and 12 individuals per colony. Distributed earlier hydroid M. platyphylla was not met in any area of the transect, or in the immediate vicinity.

The reefs on the Tho Chu now meet only a few members of the family Acroporidae, which are the basic element of all living reefs and usually form the basis of their (reef) species diversity and a high degree of coverage of live coral substrate $[35,39-43]$. Species diversity of corals, their coverage of the substrate and slow of their growth with increasing amounts of sediment have been noted in many publications [16,44-48]. Further, the strong deposit may hold coral larvae from settling and cause high mortality after attachment to the substrate by mechanical 
abrasion. All this leads to a fundamental change in the community scleractinian and possible power macrophytes and other competitors of corals [49].

In general, clearly visible irregularities and changes are observed in the zonal structure of the reef, so the composition and structure of reef communities of the island Tho Chu are changed. Nevertheless, it is equally obvious that reef communities are gradually recovering. In addition, it is hoped that after some time it will return to its previous state and species diversity, which consisted of more than five hundred species of coral and abundant species associated macrobenthos.

Especially because there are, opportunities to restore reefs through the replenishment of coral, larvae and aquatic organisms associated with other reef community. To the south of the island (in the distance of one mile $9^{\circ} 16^{\prime} \mathrm{N}$, $103^{\circ} 21^{\prime} \mathrm{E}$ ) there is a bank with depths ranging from 4 to 13 meters from the optimally developed noticeably damaged by typhoon coral community. There's the usual form for the settlement of various coral reefs more than 100 species, many common, at least 20 species Acropora, (Figure 8) and related corallobionts typical Vietnamese optimal reef community: T. crocea, T. squamosa, L. cristagalli, A. ventricosa Lambis lambis, L. hiragra, C. tigris, $M$. arabica, Acantaster planci, C. novaeguineae, L. laevigata, $H$. atra, $S$. variegatus. D. setosum, E. diadema and so on. In 2 - 3 years after calcareous substrate formation the dominance of reef building coral colonies becomes appreciable. The climax of the secondary succession, where Acropora community is formed, seems to be reach 4 - 6 years after the start of the succession, as long as the coral reefs remain in good health and are not subjected to large disturbance such as coral bleaching, sedimentation, typhoons or other bad factors [50,51].

\section{Acknowledgements}

The author is grateful to I. Budin, A. G. Goloseev, A. A. Gutnick, N. I. Selin, Tran Dinh Nam, Dao Tan Ho for his

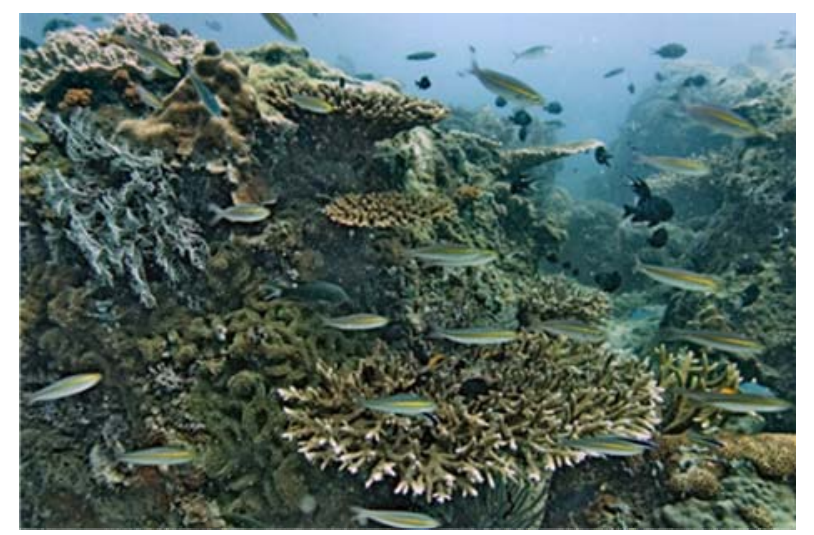

Figure 8. Reef communities in optimal conditions at the bank, depth $7 \mathrm{~m}$. help in the study communities, the definition of flora and fauna.

\section{REFERENCES}

[1] D. L. Bryant, J. W. Burke, Mc. Manus and M. Spalding, "Reefs at Risk. A Map Based Indicator of Threats to the World's Coral Reefs," World Resources Institute, Washington DC, 1998.

[2] C. R. Wilkinson, "Status of Coral Reefs of the World: 2000," Australian Institute of Marine Science, Townsville, 2000 .

[3] T. A. Gardner, I. M. Côté, J. A. Gill, A. Grant and A. R. Watkinson, "Long-Term Region-Wide Declines in Caribbean Corals," Science, Vol. 301, No. 5635, 2003, pp. 958960. http://dx.doi.org/10.1126/science.1086050

[4] W. F. Precht, A. W. Bruckner, R. B. Aronson and R. J. Bruckner, Endangered Acroporid Corals of the Caribbean," Coral Reefs, Vol. 21, No. 1, 2002, pp. 41-42.

[5] C. S. Rogers and J. Beets, "Degradation of Marine Ecosystems and Decline of Fishery Resources in Marine Protected Areas in the US Virgin Islands," Environmental Conservation, Vol. 24, No. 4, 2001, pp. 312-322.

[6] J. Geister, "The Influence of Wave Exposure on the Ecological Zonation of Caribbean Reefs," Proceedings of the 3rd International Coral Reef Symposium, Miami, 1977, Vol. 1, pp. 23-39.

[7] P. Blanchon, "Architectural Variation in Submerged ShelfEdge Reefs: The Hurricane-Control Hypothesis," Proceedings of the 8th International Coral Reef Symposium, Okinawa, 1997, Vol. 1, pp. 547-554.

[8] J. H. Connell, "Diversity in Tropical Rainforests and Coral Reefs," Science, Vol. 199, No. 4335, 1978, pp. 1302-1309. http://dx.doi.org/10.1126/science.199.4335.1302

[9] M. Harmelin-Vivien, "The Effects of Storms and Cyclones on Coral Reefs: A Review," Journal of Coastal Research, Vol. 12, 1994, pp. 211-231.

[10] M. Harmelin-Vivien and P. Laboute, "Catastrophic Impact of Hurricanes on Atoll Outer Reef Slopes in Tuamotu (French Polynesia)," Coral Reefs, Vol., 5, No. 2, 1986, pp. 55-62. http://dx.doi.org/10.1007/BF00270353

[11] Yu. Ya. Latypov and N. I. Selin, "Changes of Reef Community near $\mathrm{Ku}$ Lao Cham Islands (South China Sea) after Sangshen Typhoon," American Journal of Climate Change, Vol. 1, No. 1, 2012, pp. 41-47. http://dx.doi.org/10.4236/ajcc.2012.11004

[12] L. M. Harmelin-Vivien and P. Laboute, "Catastrophic Impact of Hurricanes on Atoll Outer Reef Slopes in the Tuamotu (French Polynesia)," Coral Reefs, Vol. 5, No. 2, 1986, pp. 55-62. http://dx.doi.org/10.1007/BF00270353

[13] D. Yellowleess, "Land Use Patterns and Nutrient Loading of the Great Barrier Reef Region: Proceedings of the Workshop Held at the James Cook University of North Queensland," Sir George Fisher Centre for Tropical Marines Studies and James Cook University of North Queensland, Queensland, 1991. 
[14] P. R. F. Bell, "Eutrophication and Coral Reefs-Some Examples in the Great Barrier Reef Lagoon," Water Research, Vol. 26, No. 5, 1992, pp. 553-568. http://dx.doi.org/10.1016/0043-1354(92)90228-V

[15] Y. Y. Latypov, "Coral Communities of the Namsu Islands (Gulf of Siam, South China Sea)," Marine Ecology Progress Series, Vol. 29, 1986, pp. 261-270. http://dx.doi.org/10.3354/meps029261

[16] Yu. Ya. Latypov, "Macrobenthos Communities of CoralReefs of the An Thoi Archipelago, South China Sea," Russian Journal of Marine Biology, Vol. 26, No. 1, 2000, pp. 22-30.

[17] Yu. Ya. Latypov, "Communities of Coral Reefs of Central Vietnam," Russian Journal of Marine Biology, Vol. 27, No. 4, 2001, pp. 197-200. http://dx.doi.org/10.1023/A:1011939501255

[18] WWF Vietnam Marine Conservation Southern Survey Team, "Survey Report on the Biodiversity Resource Utilization and Conservation Potential of PhuQuoc Islands, Kien Giangprovince, Gulf of Thailand," Gland, Switzerland, 1994.

[19] Yu. Ya. Latypov, "Community Structure of Scleractinian Reefs in the Baitylong Archipelago (South China Sea)," Asian Marine Biology, Vol. 1-2, 1995, pp. 27-37.

[20] Yu. Ya. Latypov, "Coral Reefs of the Gulf of Tonkin," Vestnik DVO RAN, No. 2, 1997, pp. 92-98.

[21] Yu. Ya. Latypov, "Benthic Communities of Coral Reefs of Tho Chu Island, Bay of Thailand, South China Sea," Biologia Morya, Vol. 25, No. 3, 1999, pp. 201-208.

[22] Yu. Ya. Latypov, "Reef-Building Corals and Reefs of Vietnam. 1. The Gulf of Siam," Biologia Morya, Vol. 29, No. 3, 2003, pp. 155-165.

[23] C. G. J. Petersen, "The Animal Association of the Sea Bottom in the North Atlantic," Kobenhavn Berlin Biology Stantion, Vol. 22, 1914, pp. 89-98.

[24] Y. Loya and L. B. Slobodkin, "The Coral Reefs of Elate (Gulf of Elate. Red Sea)," Journal of Sampling ZoologySociety London, Vol. 28, 1971, pp. 117-140.

[25] J. E. N. Veron and M. G. S. Smith, "Coral ID: An Electronic Key to the Zooxanthellate Scleractinian Corals of the World," Australian Institute of Marine Science, TownSwill, 2004.

[26] Yu. Ya. Latypov, "The Common Coral of Vietnam: Field Handbook," Far Eastern National University Press, Vladivostok, 2006.

[27] S. Weinberg, "A Comparison of Coral Reef Survey Methods," Bijdragen Tot De Dierkunde, Vol. 51, No. 2, 1981, pp. 199-218.

[28] W. Leujak and R. F. G. Ormond, "Comparative Accuracy and Efficiency of Six Coral Community Survey Methods," Journal of Experimental Marine Biology Ecology, Vol. 351, No. 1-2, 2007, pp. 168-187. http://dx.doi.org/10.1016/i.jembe.2007.06.028

[29] S. Mandaville, "Benthic Macroinvertebrates in Freshwater-Taxa Tolerance Values, Metrics, and Protocols, Project H-1. (Nova Scotia. Soil \& Water Conservation Society of Metro Halifax)," 2002.

[30] Y. Loya, "The Red Sea Coral Stylophora Pistillata Is an
Rstrategist," Nature, Vol. 259, No. 5543, 1976, pp. 478480. http://dx.doi.org/10.1038/259478a0

[31] M. Pichon, "Dynamic Species of Coral Reef Benthic Structures and Zonation," Proceeding 4th International Coral Reef Symposium, Manila, 1981, Vol. 1, pp. 581594.

[32] C. R. C. Sheppard, "Coral Population on Reef Slopes and Their Major Controls," Marine Ecology Progress Series, Vol. 7, 1982, pp. 83-115. http://dx.doi.org/10.3354/meps007083

[33] Yu. Ya. Latypov, "Encrusting Protected Reef Hon Nai in Cam Ranh Bay in the South China Sea," Natural Science, Vol. 4, No. 1, 2012, pp. 14-21. http://dx.doi.org/10.4236/ns.2012.41003

[34] Yu. I. Sorokin, "Ekosistemykorallovykhrifov," (Ecosystems of Coral Reefs), Nauka, Moscow, 1990.

[35] Yu. Ya. Latypov, "Benthic Communities of Coral Reefs of Con Dao Islands, South China Sea," Biologia Morya, Vol. 5-6, 1993, pp. 40-53.

[36] Yu. Ya. Latypov, "Reef-Building Corals of Vietnam as a Part of the Indo-Pacific Reef Ecosystem," Russian Journal of Marine Biology, Vol. 31, 2005, pp. S34-S40. http://dx.doi.org/10.1007/s11179-006-0013-5

[37] H. Ditlev, "Zonation of Corals (Scleractinia Coelenterata) on Intertidal Reef Flats at Ko Phuket, Eastern Indian Ocean," Marine Biology, Vol. 47, No. 1, 1978, pp. 29-39. http://dx.doi.org/10.1007/BF00397016

[38] H. W. Ducklow and R. Mitchell, "Bacteria in Mucus Layers on Living Corals," Limnology and Oceanography, Vol. 24, No. 4, 1979, pp. 715-725. http://dx.doi.org/10.4319/10.1979.24.4.0715

[39] P. F. Holthus, J. E. Maragos and C. W. Evans, "CoralReef Recovery Subsequent to the Freshwater Kill of 1965 in Kaneohe Bay, Hawaii," Pacific Science, Vol. 43, No. 2, 1989, pp. 122-134.

[40] K. O. Amar, N. E. Chadwick and B. Rinkevich, "Coral Planulae as Dispersion Vehicles: Biological Properties of Larvae Released Early and Late in the Season," Marine Ecology Progress Series, Vol. 350, 2007, pp. 71-78. http://dx.doi.org/10.3354/meps07125

[41] Yu. Ya. Latypov, "Scleractinian Corals of South Vietnam," Biologia Morya, No. 5, 1987, pp. 111-119.

[42] M. B. Best, B. W. Hoeksema, W. Moka, H. Moli and I. N. Sutarna, "Recent Scleractinian Corals Species Collected during the Snellius-II Expedition in Eastern Indonesia," Netherlands Journal of Sea Research, Vol. 23, No. 2, 1989, pp. 7-115. http://dx.doi.org/10.1016/0077-7579(89)90005-7

[43] J. E. N. Veron and G. Hodgson, "Annotated Checklist of the Hermatypic Corals of the Philippines," Pacific Science, Vol. 43, No. 3, 1989, pp. 234-287.

[44] J. E. N. Veron, "Corals in Space and Time: The Biogeography and Evolution of the Scleractinia," Cornell University Press, New York, 1995.

[45] S. Vo and G. Hodgson, "Coral Reefs of Vietnam: Recruitment Limitation and Physical Forcing," Proceeding of the 8th Internet Coral Reef Symposium, Okinawa, 1997, Vol. 1, pp. 477-482. 
[46] K. Sakai and M. Nishihira, "Immediate Effect of Terrestrial Runoff on a Coral Community near a River Mouth in Okinawa," Galaxea, Vol. 10, 1991, pp. 125-134.

[47] K. P. Sebens, "Biodiversity of Coral Reefs: What Are We Losing and Why?" American Zoologist, Vol. 34, 1994, pp. 115-133.

[48] N. G. Andres and J. D. Witman, "Trends in Community Structure on a Jamaican Reef," Marine Ecology Progress Series, Vol. 118, 1985, pp. 305-310. http://dx.doi.org/10.3354/meps118305

[49] B. Salvat, "Dredging in Coral Reefs," In: B. Salvat, Ed., Human Impact on Coral Reefs: Facts and Recommendations, Museum National D’histoire Naturelle et École-
Pratique des Hautesétudes, Antenne de Tahiti \& Centre de l'Environnement, California, 1987, pp. 165-184.

[50] D. R. Choi, "Ecological Succession of Reef Cavity-Dwellers (Coelobites) in Coral Rubble," Bulletin Marine of Science, Vol. 35, No. 1, 1984, pp. 72-79.

[51] H. Ohba, K. Hashimoto, K. Shimoike, T. Shibuno and Y. Fujioka, "Secondary Succession of Coral Reef Communities at Urasoko Bay, Ishigaki Island, the Ryukyus (Southern Japan)," Proceeding of the 11th Internet Coral Reef Symposium Ft Lauderdale, Florida, 7-11 July 2008, pp. 319-327. 